\title{
Diagnosis and epidemiology of canine leishmaniasis in southeastern Bahia, Brazil
}

\author{
T.N.A. Oliveira ${ }^{1}$, P.E.B. Guedes ${ }^{1}$, G.B. Souza ${ }^{1}$, F.S. Carvalho ${ }^{2}$, \\ R.S. Alberto Carlos ${ }^{3}$, G.R. Albuquerque ${ }^{3}$, A.D. Munhoz ${ }^{3}$ and F.L. Silva ${ }^{3}$ \\ ${ }^{1}$ Programa de Pós-Graduação em Ciência Animal, \\ Universidade Estadual de Santa Cruz, Ilhéus, BA, Brasil \\ ${ }^{2}$ Programa de Pós-Graduação em Genética e Biologia Molecular, \\ Universidade Estadual de Santa Cruz, Ilhéus, BA, Brasil \\ ${ }^{3}$ Departamento de Ciências Agrárias e Ambientais, \\ Universidade Estadual de Santa Cruz, Campus Soane Nazaré de Andrade, \\ Hospital Veterinário, Ilhéus, BA, Brasil
}

Corresponding author: F.L. Silva

E-mail: fabiana.lessa@gmail.com

Genet. Mol. Res. 15 (3): gmr.15038684

Received March 31, 2016

Accepted May 5, 2016

Published September 2, 2016

DOI http://dx.doi.org/10.4238/gmr.15038684

Copyright (C) 2016 The Authors. This is an open-access article distributed under the terms of the Creative Commons Attribution ShareAlike (CC BY-SA) 4.0 License.

ABSTRACT. Leishmaniasis is a disease caused by protozoa of
the genus Leishmania. Two distinct forms are recognized: visceral
leishmaniasis (VL) and cutaneous leishmaniasis (CL). In the Americas,
the causative agent of VL is L. infantum chagasi, whereas L. braziliensis
is principally responsible for CL. Domestic dogs constitute the main
source of VL in urban environments, and have also been implicated in
CL epidemiology. We carried out molecular and serological surveys to
detect Leishmania infection in dogs from the municipality of Ituberá
in Bahia, Brazil. Furthermore, we identified risk factors associated
with illness in dogs from this locality. Blood samples were collected
from 399 dogs and tested using an indirect immunofluorescence assay 
(IFA) and polymerase chain reaction (PCR) to detect Leishmania spp antibodies and L. infantum chagasi and L. braziliensis DNA, respectively. Dogs were clinically evaluated and tissue samples from those exhibiting skin lesions were examined for parasites. In addition, the dog owners completed an epidemiological questionnaire to identify factors associated with infection. Skin lesions consistent with CL were found on $37(9.3 \%)$ of the evaluated animals, but parasitological examination was negative for all samples. The IFA returned positive results for $60(15 \%)$ dogs. PCR identified DNA from L. braziliensis in $86(21.6 \%)$ animals, where as all samples proved negative for $L$. infantum chagasi. The 134 dogs (33.6\%) testing positive using IFA and/ or PCR were considered infected, and of these, only 13 demonstrated skin lesions. Animals from rural areas were 3.39-times more likely to be infected compared to those in urban environments.

Key words: Leishmania spp.; Dogs; Serology; Molecular biology; Risk factors

\section{INTRODUCTION}

Leishmaniasis is a zoonosis caused by heteroxenous digenetic intracellular protozoa of the genus Leishmania, and transmitted to vertebrate hosts (mammals) by female sandfly bites. This disease has a world wide distribution, affecting 88 countries across the Middle East, Africa, Asia, Europe, and the Americas (Ashford, 2000). According to clinical manifestations, leishmaniasis can be divided into two categories: visceral (VL) and cutaneous (CL) (Ministério da Saúde Brasil, 2010).

$\mathrm{VL}$, or kala azar, is a chronic zoonotic disease affecting humans, wildlife, and domestic animals. In the Americas, this condition is caused by Leishmania infantum chagasi. In Latin America, it has been documented in at least 12 countries, with approximately $90 \%$ of reported cases occurring in Brazil, the northeast region of which is particularly affected (Ministério da Saúde Brasil, 2013). Domestic dogs (Canis familiaris) play a fundamental role in maintaining this disease in endemic areas, asthey act as reservoirs of infection in both rural and urban environments (Dantas-Torres, 2007; Werneck et al., 2007).

CL has been described from the furthest southern United States to northern Argentina, with the exception of Chile and Uruguay. According to the World Health Organization, more than one million new cases of human CL are diagnosed worldwide each year. Brazil together with Afghanistan, Algeria, Colombia, Iran, Pakistan, Peru, Saudi Arabia, and Syria accounts for $90 \%$ of these cases (World Health Organization, 2015). In Brazil, seven dermotropic Leishmania species are recognized, the most important being Leishmania (Viannia) braziliensis (Ministério da Saúde Brasil, 2010). Of the CL diagnoses made in this country, $90.14 \%$ are recorded in the North, Northeast, and Midwest regions. In Bahia State, this disease is present in all regions and $58.5 \%$ of municipalities. Despite being originally associated with wild animals, American cutaneous leishmaniasis has been reported in domestic contexts, suggesting that domestic and peridomestic animals, particularly dogs, act as reservoirs in such environments (Marzochi and Marzochi, 1994). This possibility maybe supported by the fact that certain locations with high numbers of human cases are associated with elevated canine

Genetics and Molecular Research 15 (3): gmr.15038684 
infection rates (Falqueto et al., 1986; Dantas-Torres, 2007; Pittner et al., 2009).

Canine leishmaniasis affects thousands of animals in Brazil and other countries around the world. In Northeast Brazil, the prevalence of Leishmania infection in dogs ranges from 21.7 to 54.7\% (Paranhos-Silva et al., 1996; Rondon et al., 2008; Carvalho et al., 2015; Leça-Júnior et al., 2015). Although previous investigations have been carried out in the state of interest to the present study, the prevalence of Leishmania infection among dogs and the identity of the species involved need to be determined in each region, because human leishmaniasis is endemic in many municipalities. Considering the importance of dogs in the transmission of VL and their possible role as domestic reservoirs in CL, we aimed to identify L. braziliensis and L. infantum chagasi infection in the canine population of an endemic CL area in northeastern Brazil, and the associate drisk factors.

\section{MATERIAL AND METHODS}

\section{Study area}

This study was conducted in the municipality of Ituberá, in the southeast of Bahia State $\left(13^{\circ} 43^{\prime} \mathrm{S}, 39^{\circ} 08^{\prime} \mathrm{W}\right)$. The city has a total area of $417 \mathrm{~km}^{2}$ and a population of 26,591 , at a density of 71.5 inhabitants $/ \mathrm{km}^{2}$ (Instituto Brasileiro de Geografia e Estatística, 2015). The region has a hot and humid climate, with an average temperature of $25.3^{\circ} \mathrm{C}$, varying by $5.6^{\circ} \mathrm{C}$ annually, and $1800-2400 \mathrm{~mm}$ annual rainfall distributed throughout the year. The area is representative of the Atlantic Forest biome.

\section{Animals and sampling}

Sample size calculations were performed using the Epi Info 3.5.2 software with $95 \%$ confidence intervals, considering the size of the dog population to be $12 \%$ of the local human population (Escobar Cifuentes, 1988). The frequency of infected animals was estimated as $50 \%$, because no previous studies have measured this figure in this region, and the sampling error was $5 \%$.

This study included 399 adult dogs domiciled in the city of Ituberá. Sampling took place between May and September 2012 and was conducted evenly throughout the city neighborhoods, covering both rural and urban areas, in which 59 and 340 dogs were examined, respectively. The population of each district was determined as a proportion of the total population. The Ethics Committee on Animal Use of Universidade Estadual de Santa Cruz approved this study under protocol No. 020/11.

With the permission of their owners, the dogs received an initial clinical assessment for the presence of skin lesions. By puncture of the jugular or cephalic vein, approximately $5 \mathrm{~mL}$ venous blood was then collected in plastic tubes containing or lacking an anticoagulant (ethylenediaminetetraacetic acid; EDTA) for molecular biology procedures and serological tests, respectively.

\section{Epidemiological data}

Dog owners that participated in the study completed an epidemiological questionnaire to identify factors associated with infection. It covered the general characteristics of the dog, environmental factors, and contact with other animals. The data were recorded individually.

Genetics and Molecular Research 15 (3): gmr.15038684 
T.N.A. Oliveira et al.

\section{Parasitological diagnosis}

Tissue samples from dogs with skin lesions consistent with CL were collected for direct identification of parasites. The animals were physically restrained and $0.2 \%$ lidocaine was applied to the area around the lesion. Samples were obtained by scraping lesions with scalpel blades. The collected material was placed on glass slides and treated with Giemsa stain before being assessed by light microscopy to identify amastigotes of Leishmania spp.

\section{Serology}

Blood samples lacking anticoagulant were centrifuged at $1292 \mathrm{~g}$ for $15 \mathrm{~min}$ to obtain serum, which was stored at $-20^{\circ} \mathrm{C}$. Detection of anti-Leishmania antibodies was then performed by indirect immunofluorescence assay (IFA) using glass slides sensitized with $L$. infantum chagasi (Jaboticabal strain) and treated with an anti-dog immunoglobulin G fluorescein isothiocyanate-conjugated antibody (F7884; Sigma, St. Louis, MO, USA). The method was adapted from that previously described by Oliveira et al. (2008). Serological titers $\geq 1: 40$ were considered positive.

\section{Molecular biology}

Blood samples containing EDTA were centrifuged at $1292 \mathrm{~g}$ for $15 \mathrm{~min}$ to separate the buffy coat. DNA was extracted using an Easy-DNA kit (Invitrogen, Carlsbad, CA, USA) and stored at $-20^{\circ} \mathrm{C}$. The final DNA concentration of each sample was determined by spectrophotometry, based on optical density at $260 \mathrm{~nm}$.

The primers B1 (5'-GGGGTTGGTGTAATATAGTGG-3') and B2 (5'-CTAATTGTGC ACGGGGAGG-3'), previously described by de Bruijn and Barker (1992), were used for amplification of a 750-bp fragment of $L$. braziliensis DNA. The polymerase chain reaction (PCR) conditions employed were similar to those outlined by Reithinger et al. (2000). Each 25- $\mu \mathrm{L}$ PCR comprised $17 \mu \mathrm{L}$ PCR SuperMix (Invitrogen), which included 1 U Taq DNA polymerase and $0.6 \mathrm{mM} \mathrm{MgCl}, 20$ pmol each primer, and $100 \mathrm{ng}$ DNA. Amplification was performed using a Biocycler MJ96G (Applied Biosystems do Brasil Ltda) thermocycler and the following conditions: initial denaturation for $5 \mathrm{~min}$ at $94^{\circ} \mathrm{C}$, followed by 35 cycles of $94^{\circ} \mathrm{C}$ for $1 \mathrm{~min}, 59^{\circ} \mathrm{C}$ for $1 \mathrm{~min}$, and $72^{\circ} \mathrm{C}$ for $1 \mathrm{~min}$, before a final extension at $72^{\circ} \mathrm{C}$ for $7 \mathrm{~min}$. PCR products were electrophoresed on a $2 \%$ agarose gel stained with ethidium bromide and bands were visualized with a transilluminator. A L. braziliensis strain pure culture (MHOM/ $\mathrm{BR} / 3456$ ) and ultrapure water were used as positive and negative controls, respectively.

Primers RV1 (5'-CTTTTCTGGTCCCGCGGGTAGG-3') and RV2 (5'-CCACCTGGC CTATTTTACACCA-3') were used to amplify a 145 -bp fragment of $L$. infantum chagasi DNA (Ravel et al., 1995). The PCR conditions were adapted from those previously described by Lachaud et al. (2002). Each PCR contained $17 \mu \mathrm{L}$ PCR SuperMix, 20 pmol each primer, and $100 \mathrm{ng}$ DNA, in a final volume of $25 \mu \mathrm{L}$. Cycling conditions were as follows: initial denaturation for $5 \mathrm{~min}$ at $94^{\circ} \mathrm{C}$, then 35 cycles of $94^{\circ} \mathrm{C}$ for $45 \mathrm{~s}, 59^{\circ} \mathrm{C}$ for $45 \mathrm{~s}$, and $72^{\circ} \mathrm{C}$ for $45 \mathrm{~s}$, followed by a final extension at $72^{\circ} \mathrm{C}$ for $7 \mathrm{~min}$. PCR products were subjected to electrophoresis on a $2 \%$ agarose gel stained with ethidium bromide, of which images were recorded. A L. infantum chagasi strain pure culture (MHOM/BR2000/Merivaldo) was used as a positive control, and ultrapure water as a negative control.

Genetics and Molecular Research 15 (3): gmr.15038684 


\section{Statistical analysis}

Statistical analysis was performed using Epi Info 3.5.2, taking into account exposure variables and the results of serological and molecular tests. Data were compared using the Fisher exact test and the chi-square test, and $\mathrm{P}$ values $<0.05$ were considered significant. Variables with $\mathrm{P}$ values less than or equal to 0.2 were subjected to unconditional multivariate logistic regression analysis, with the final model built using the input and output variables (the backward elimination). The degree of agreement between the serology and PCR results was determined by calculating the Kappa $(k)$ values with $95 \%$ confidence intervals.

\section{RESULTS}

Skin lesions, found mainly in the ears, scrotum, and mucocutaneous junction of the nose, were observed on $37(9.3 \%)$ dogs. These presented mostly as chronic, single, and ulcerated or ulcerated/crusted lesions. Cytological examination failed to reveal the presence of Leishmania spp amastigotes in the evaluated samples.

The IFA for L. braziliensis returned positive results for $60(15 \%)$ dogs, and showed antibody titers ranging from 1:40 to 1:640. Using PCR, L. braziliensis DNA was detected in $86(21.6 \%)$ of the animals examined (Table 1), whereas none tested positive for L. infantum chagasi.

A total of 134 dogs (33.6\%) were considered to be infected on the basis of positive IFA and/or PCR results. Of these, 13 (9.97) had cutaneous lesions suggestive of CL, eight of which tested positive by PCR, six by serology, and one by both techniques (Table 1). The calculated Kappa value with a $95 \%$ confidence interval was $k=-0.016(-0.111-0.080)$ for serology and PCR, indicating a low agreement between the results of these methods.

Table 1. Comparison of results obtained by serological and molecular methods.
\begin{tabular}{c|c|c|c|c}
\hline \multirow{3}{*}{ PCR } & & \multicolumn{3}{|c}{ Serology } \\
\cline { 2 - 5 } & & Positive & Negative & Total \\
\hline & Positive & 12 & 74 & 86 \\
\cline { 2 - 5 } & Negative & 48 & 265 & 313 \\
\cline { 2 - 5 } & Total & 60 & 339 & 399 \\
\hline
\end{tabular}

Kappa $=-0.016 . \mathrm{PCR}=$ polymerase chain reaction.

Basic health-related facilities, such as garbage collection, septic tanks, sewerage, and bathrooms, were present in $85.5,25.3,51.6$, and $84.4 \%$ of households visited, respectively. Respondents reported the presence of animals outside the home, including cats $(69.9 \%)$, stray dogs $(48.9 \%)$, and rodents $(37.3 \%)$. Vacant land, banana trees, fruit trees, rearing of chickens, and breeding of birds were observed in 52.4, 55.1, 83.5, 55.6, and $7.3 \%$ of homes, respectively.

Among the variables assessed, only habitat acted as a risk factor, with dogs from rural areas being 3.39-times more likely to be infected than those from urban regions (Tables 2 and 3). 
Table 2. Factors associated with Leishmania braziliensis infection in dogs having tested positive by serological and/or molecular methods.

\begin{tabular}{|c|c|c|c|c|c|c|c|}
\hline \multicolumn{2}{|l|}{ Variable } & $\mathrm{N}$ & Positive & Prevalence $(\%)$ & OR & $95 \% \mathrm{CI}$ & P value \\
\hline \multirow[t]{2}{*}{ Age } & $1-2$ years & 163 & 52 & 31.9 & 1.13 & \multirow[t]{2}{*}{$0.74-1.74$} & \multirow[t]{2}{*}{0.63} \\
\hline & $>2$ years & 236 & 82 & 34.7 & 1 (Reference) & & \\
\hline \multirow[t]{2}{*}{ Sex } & Male & 236 & 83 & 35.1 & 1.19 & \multirow[t]{2}{*}{$0.78-1.82$} & \multirow[t]{2}{*}{0.48} \\
\hline & Female & 163 & 51 & 31.3 & 1 (Reference) & & \\
\hline \multirow[t]{2}{*}{ Habitat } & Rural & 59 & 32 & 54.2 & 2.76 & \multirow[t]{2}{*}{$1.57-4.85$} & \multirow[t]{2}{*}{$<0.01$} \\
\hline & Urban & 340 & 102 & 30 & 1 (Reference) & & \\
\hline \multirow[t]{2}{*}{ Contact with cats } & Yes & 279 & 97 & 34.7 & 1.02 & \multirow[t]{2}{*}{$0.64-1.61$} & \multirow[t]{2}{*}{0.98} \\
\hline & No & 120 & 37 & 30.8 & 1 (Reference) & & \\
\hline \multirow[t]{2}{*}{ Contact with stray dogs } & Yes & 195 & 73 & 37.4 & 1.4 & \multirow[t]{2}{*}{$0.92-2.16$} & \multirow[t]{2}{*}{0.13} \\
\hline & No & 204 & 61 & 29.9 & 1 (Reference) & & \\
\hline \multirow[t]{2}{*}{ Contact with rodents } & Yes & 149 & 48 & 32.2 & 0.89 & \multirow[t]{2}{*}{$0.57-1.37$} & \multirow[t]{2}{*}{0.68} \\
\hline & No & 250 & 86 & 34.4 & 1 (Reference) & & \\
\hline \multirow[t]{2}{*}{ Presence of vacant land } & Yes & 209 & 65 & 31.1 & 0.79 & \multirow[t]{2}{*}{$0.52-1.2$} & \multirow[t]{2}{*}{0.31} \\
\hline & No & 190 & 69 & 36.3 & 1 (Reference) & & \\
\hline \multirow[t]{2}{*}{ Presence of banana tree } & Yes & 220 & 80 & 36.4 & 1.33 & \multirow[t]{2}{*}{$0.86-2.0$} & \multirow[t]{2}{*}{0.23} \\
\hline & No & 179 & 54 & 30.1 & 1 (Reference) & & \\
\hline \multirow[t]{2}{*}{ Presence of fruit trees } & Yes & 333 & 117 & 35.1 & 1.56 & \multirow[t]{2}{*}{$0.86-2.83$} & \multirow[t]{2}{*}{0.18} \\
\hline & No & 66 & 17 & 25.7 & 1 (Reference) & & \\
\hline \multirow[t]{2}{*}{ Presence of chicken } & Yes & 222 & 78 & 35.1 & 1.17 & \multirow[t]{2}{*}{$0.76-1.78$} & 0.52 \\
\hline & No & 177 & 56 & 31.6 & 1 (Reference) & & \\
\hline Presence of birds & Yes & 29 & 12 & 41.4 & 1.43 & $0.66-3.1$ & 0.47 \\
\hline & No & 370 & 122 & 33 & 1 (Reference) & & \\
\hline Presence of sewerage & Yes & 206 & 66 & 32.0 & 0.86 & $0.57-1.31$ & 0.57 \\
\hline & No & 193 & 68 & 35.2 & 1 (Reference) & & \\
\hline Presence of septic tank & Yes & 101 & 29 & 28.7 & 0.74 & $0.45-1.21$ & 0.28 \\
\hline & No & 298 & 105 & 35.2 & 1 (Reference) & & \\
\hline Presence of bathroom & Yes & 336 & 109 & 32.4 & 0.73 & $0.42-1.27$ & 0.33 \\
\hline & No & 63 & 25 & 39.7 & 1 (Reference) & & \\
\hline Presence of garbage & Yes & 341 & 109 & 31.9 & 0.62 & $0.35-1.09$ & 0.13 \\
\hline collection & No & 58 & 25 & 43.1 & 1 (Reference) & & \\
\hline
\end{tabular}

$\mathrm{OR}=$ odds ratio $; 95 \% \mathrm{CI}=95 \%$ confidence interval.

Table 3. Final model of non-conditional logistic regression of factors associated with Leishmania braziliensis in dogs from Ituberá, Bahia, Brazil.

\begin{tabular}{l|c|c|c}
\hline Variable & Odds ratio & $95 \%$ confidence interval & P value \\
\hline Habitat & 2.77 & $1.58-4.85$ & 0.0004 \\
\hline
\end{tabular}

$\mathrm{P}=0.003$, likelihood $=0.004$.

\section{DISCUSSION}

In this study, most of the dogs considered to be infected were asymptomatic. The skin lesions observed on symptomatic dogs animals were similar to those described by other authors (Serra et al., 2003). Silveira et al. (1996) and Serra et al. (2003) also recorded large numbers of asymptomatic animals, with 16.7 and $21.7 \%$ of seropositive dogs in their investigations exhibiting skin lesions, respectively. According to Passos et al. (1996), injuries caused by CL in dogs alternate between periods of spontaneous healing and recurrence, which may explain the small number of animals with lesions at the time of observation. Ferrer (2002) reported that the number of asymptomatic animals in endemic regions maybe as high as $80 \%$, and that such dogs, which cannot be identified owing to the absence of clinical symptoms, can act as a source of infection for vectors of the disease. 
The absence of amastigotes revealed by cytological examination indicates the low sensitivity of this technique for the diagnosis of CL in dogs, as demonstrated recently by LeçaJúnior et al. (2015). Such results can be explained by the scarcity of parasites in the lesions of dogs infected by L. braziliensis, as described by Zanzarini et al. (2005). Moreover, according to Furtado (1980), the likelihood of detecting a parasite diminishes as the time between the lesion's appearance and a parasitological diagnosis increases. The sensitivity of this diagnostic method for $L$. braziliensis infection is approximately $100 \%$ in the first two months following onset of symptoms, $75 \%$ at six months, and $20 \%$ after 12 months (Furtado, 1980). This suggests that the animals in this study had chronic leishmaniasis, reducing the chance of parasite detection. Schubach et al. (2001) also highlighted the occurrence of secondary bacterial infections that can further hinder the visualization of amastigotes in direct parasitological examination. In addition, the skin lesions observed in this study were nonspecific, and may be related to other dermatopathies.

Regarding serological diagnosis, the results obtained here are similar to those published by Silveira et al. (1996), who reported that $18.2 \%$ of animals in the State of Paraná are seropositive. However, variation in the prevalence rate is very high (2.16 to $54.7 \%)$ when considering the values estimated by other authors (Pereira et al., 2008; Reis et al., 2011; Araújo et al., 2014; Carvalho et al., 2015; Leça-Júnior et al., 2015). Although IFAs are widely employed for their convenience and low cost, their use is controversial owing to low levels of detectable serum antibodies and the possibility of cross-reactions (Antunes Uchôa et al., 2001). Serological diagnosis results vary depending on the stage of infection (Heusser Júnior et al., 2010). According to Antunes Uchôa et al. (2001), higher levels of specific antibodies are produced when multiple cutaneous lesions are present in the later stages of infection, and in cases with simple skin lesions and lymphatic system involvement. In addition, seroconversion may take up to 22 months; therefore, during this period, it is not possible to detect infected animals by serological methods (Solano-Gallego et al., 2005).

PCR for the diagnosis of CL can be performed using peripheral venous blood and samples from normal or lesioned skin biopsies and lymph node puncture (Reithinger et al., 2000; Velasquez et al., 2006). However, PCR based on blood samples is considered by some authors to be less sensitive, principally due to the reduced numbers of parasites in circulation (Reithinger et al., 2000; Santos et al., 2010). In this study, buffy coat was used for PCR detection of $L$. braziliensis DNA, resulting in the identification of many infected animals. Of the asymptomatic infected dogs, $72 \%$ were identified by PCR, demonstrating the effectiveness of this technique for the diagnosis of infection in these animals. Martins et al. (2010) also demonstrated the efficiency of PCR carried out using peripheral venous blood samples for detection of L. braziliensis DNA in humans with no cutaneous lesions. According to Rodrigues (2000), this method displays significantly higher sensitivity and specificity than direct testing techniques, isolation from culture, and IFA. These attributes favor the identification of subclinical cases with low parasitism rates, enabling better monitoring of treatment and more accurate assessment of disease prevalence in endemic areas (Rodrigues, 2000).

The high number of animals testing positive for L. braziliensis DNA by PCR but serologically negative by IFA may be due to the fact that seroconversion had not occurred in the assessed dogs by the time of the study. Furthermore, most of the evaluated animals were asymptomatic, which according to Antunes Uchôa et al. (2001) also reduces the possibility of detecting specific antibodies. In this study, the majority of dogs were malnourished and in poor condition, suggesting that they had weakened immune systems and were therefore unable to generate antibodies against Leishmania infection. Antunes Uchôa et al. (2001) also

Genetics and Molecular Research 15 (3): gmr.15038684 
state that the humoral immune response in CL cases is weak, and in most cases mediated by $\mathrm{T}$ lymphocytes. In addition, Martins et al. (2010) found that PCR tests can be positive even years after lesions have healed. They found that of the 93 patients in their study without lesions, 37 (39.8\%) were PCR positive, indicating the presence of parasite-derived genetic material. Taken together, these data may explain why serological examination has a lower detection rate than molecular diagnosis. The absence of $L$. infantum chagasi-positive animals can be explained by the lack of sandflies in the studied region, which are involved in the transmission cycle. In a recent study undertaken by Cova et al. (2015) in the same area, the predominant sandfly species were found to be Nyssomyia whitmani (Lutzomyia whitmani; 68\%) and $N$. intermedia (Lutzomyia intermedia; 26\%), whereas the presence of Lutzomyia longipalpis, the main vector of VL, was not detected.

The results obtained from the kappa test show a low agreement between the results of serological and PCR methods and indicate the differences in the characteristics of sensitivity and specificity of the techniques, allowing to conclude that these diagnostic methods are complementary.

Regarding the epidemiological variables assessed, only habitat was identified as a risk factor, with dogs from rural areas being more exposed to infection. Similar results were obtained by Zanzarini et al. (2005), who also observed large numbers of infected animals (55.2\%) in rural areas. Reithinger and Davies (1999) suggested that more infected animals are found in rural habitats because of the proximity of non-domestic animals and dogs to disease vectors, given that transmission typically occurs in the wild. However, in a study of 429 dogs in endemic CL regions of Minas Gerais, Maywald et al. (1993) reported that only 1\% tested positive in rural areas, whereas $10.6 \%$ were found to be infected in urban environments. According to Falqueto et al. (1986), the CL transmission cycle possesses unique features in each endemic region, and data cannot always be extrapolated from one area to another. Thus, risk factors will differ in each region according to the parasites, reservoirs, and sandfly species present.

The results of this study allow us to say that the municipality of Ituberá in Bahia, an area endemic for human CL, contains many infected dogs, most of which are asymptomatic. The presence of these animals may be an indicator of the risk of this infection being transmitted to humans in this locality. Rural habitat was found to be a risk factor for infection.

\section{Conflicts of interest}

The authors declare no conflict of interest.

\section{ACKNOWLEDGMENTS}

Research supported by Fundação de Amparo à Pesquisa do Estado da Bahia (FAPESB, Salvador, Bahia) and Universidade Estadual de Santa Cruz (UESC, Ilhéus, Bahia).

\section{REFERENCES}

Antunes Uchôa CM, Barrientos Serra CM, Duarte R, Magalhães CM, et al. (2001). [Serological and epidemiological features of canine American tegumentary Leishmaniasis from Maricá, Rio de Janeiro, Brazil]. Rev. Soc. Bras. Med. Trop. 34: 563-568. http://dx.doi.org/10.1590/S0037-86822001000600011

Araújo FRF, Andre WPP, Reis PFCC, Fernandes TM, et al. (2014). Leishmaniose tegumentar americana canina na zona rural do município de São Miguel, Rio Grande do Norte. Rev. Bras. Cienc. Vet. 21: 188-191. http://dx.doi. org $/ 10.4322 /$ rbcv.2014.383

Genetics and Molecular Research 15 (3): gmr.15038684 
Ashford RW (2000). The leishmaniases as emerging and reemerging zoonoses. Int. J. Parasitol. 30: 1269-1281. http:// dx.doi.org/10.1016/S0020-7519(00)00136-3

Carvalho FS, Wenceslau AA, Albuquerque GR, Munhoz AD, et al. (2015). Leishmania (Viannia) braziliensis in dogs in Brazil: epidemiology, co-infection, and clinical aspects. Genet. Mol. Res. 14: 12062-12073. http://dx.doi. org/10.4238/2015.October.5.19

Cova BO, Fonseca EOL, Santos RF, Santos PRB, et al. (2015). Aspectos epidemiológicos da leishmaniose tegumentar americana no município de Ituberá, baixo sul da Bahia. Rev. Baiana de Saúde Pública 39 (Suppl 1): 105-124.

Dantas-Torres F (2007). The role of dogs as reservoirs of Leishmania parasites, with emphasis on Leishmania (Leishmania) infantum and Leishmania (Viannia) braziliensis. Vet. Parasitol. 149: 139-146. http://dx.doi.org/10.1016/j. vetpar.2007.07.007

de Bruijn MH and Barker DC (1992). Diagnosis of New World leishmaniasis: specific detection of species of the Leishmania braziliensis complex by amplification of kinetoplast DNA. Acta Trop. 52: 45-58. http://dx.doi.org/10.1016/0001706X(92)90006-J

Escobar Cifuentes E (1988). Program for the elimination of urban rabies in Latin America. Rev. Infect. Dis. 10 (Suppl 4): S689-S692.http://dx.doi.org/10.1093/clinids/10.Supplement 4.S689

Falqueto A, Coura JR, Barros GC, Grimaldi Filho G, et al. (1986). [Participation of the dog in the cycle of transmission of cutaneous leishmaniasis in the municipality of Viana, State of Espirito Santo, Brazil]. Mem. Inst. Oswaldo Cruz 81: $155-163$.

Ferrer L (2002). Canine leishmaniosis: evaluation of the immunocompromised patient. In: Proceedings of the 27th WSAVA (World Small Animal Veterinary Association) Congress, Granada. http://www.vin.com/proceedings/Proceedings. plx?CID=WSAVA2002\&PID=PR02653. Acessed November 13, 2015.

Furtado T (1980). Critérios para diagnóstico da leishmaniose tegumentar americana. An. Bras. Dermatol. 65: 51-86.

Heusser Júnior A, Bellato V, Souza AP, Moura AB, et al. (2010). [Canine tegumentar leishmaníasis in the town of Balneário Camboriú in the State of Santa Catarina]. Rev. Soc. Bras. Med. Trop. 43: 713-718. http://dx.doi.org/10.1590/S0037$\underline{86822010000600023}$

Instituto Brasileiro de Geografia e Estatística (2015). Ituberá demographic data. http://cidades.ibge.gov.br/xtras/perfil. php?codmun=291730. Accessed November 24, 2015.

Lachaud L, Marchergui-Hammami S, Chabbert E, Dereure J, et al. (2002). Comparison of six PCR methods using peripheral blood for detection of canine visceral leishmaniasis. J. Clin. Microbiol. 40: 210-215. http://dx.doi. org/10.1128/JCM.40.1.210-215.2002

Leça Júnior NF, Guedes PE, Santana LN, Almeida V dos A, et al. (2015). Epidemiology of canine leishmaniasis in southern Bahia, Brazil. Acta Trop. 148: 115-119. http://dx.doi.org/10.1016/j.actatropica.2015.04.008

Martins L, Alexandrino A and Guimarães G (2010). Detection of Leishmania braziliensis DNA in American tegumentary leishmaniasis patients. Rev. Saude Publica 44: 571-574.http://dx.doi.org/10.1590/S0034-89102010005000004

Marzochi MC and Marzochi KB (1994). Tegumentary and visceral leishmaniases in Brazil: emerging anthropozoonosis and possibilities for their control. Cad. Saude Publica 10 (Suppl 2): 359-375. http://dx.doi.org/10.1590/S0102$\underline{311 X 1994000800014}$

Maywald PG, Machado MI, Cruz JMC, Oliveira MG, et al. (1993). Leishmaniose tegumentar canina: inquérito soroepidemiológico em áreas rural e urbana no município de Uberlândia, Minas Gerais. Braz. J. Vet. Res. Anim. Sci. 30: $25-29$.

Ministério da Saúde Brasil (2010). Manual de vigilância da leishmaniose tegumentar americana. Editora do Ministério da Saúde, Brasília.

Ministério da Saúde Brasil (2013). Manual de vigilância e controle da leishmaniose visceral. Editora do Ministério da Saúde, Brasília.

Oliveira TMFS, Furuta PI, de Carvalho D and Machado RZ (2008). A study of cross-reactivity in serum samples from dogs positive for Leishmania sp., Babesia canis and Ehrlichia canis in enzyme-linked immunosorbent assay and indirect fluorescent antibody test. Rev. Bras. Parasitol. Vet. 17: 7-11.

Paranhos-Silva M, Freitas LA, Santos WC, Pontes-de-Carvalho LC, et al.; Grimaldi G Júnior (1996). A cross-sectional serodiagnostic survey of canine leishmaniasis due to Leishmania chagasi. Am. J. Trop. Med. Hyg. 55: 39-44.

Passos VM, Andrade AC, Silva ES, Figueiredo EM, et al. (1996). [A canine survey in a recent focus of cutaneous leishmaniasis in the city of Sabará, the metropolitan area of Belo Horizonte]. Rev. Soc. Bras. Med. Trop. 29: 323-329. http://dx.doi.org/10.1590/S0037-86821996000400003

Pereira MAVC, Tavora MPF, Vita GF and Silva VL (2008). Diagnóstico sorológico pelo método de imunofluorescência indireta (IFI) para detecção de anticorpos anti-Leishmania sp., em cães errantes do município de Campos dos Goytacazes, estado do Rio de Janeiro, no período de 2000 a 2001, após surgimento de caso humano autóctone. Ars Veterinária 24: 177-180.

Genetics and Molecular Research 15 (3): gmr.15038684 
Pittner E, Voltarelli E, Perles TF, Arraes SMAA, et al. (2009). Ocorrência de leishmaniose tegumentar em cães de área endêmica no Estado do Paraná. Arq. Bras. Med. Vet. Zootec. 61: 561-565. http://dx.doi.org/10.1590/S0102$\underline{09352009000300006}$

Ravel S, Cuny G, Reynes J and Veas F (1995). A highly sensitive and rapid procedure for direct PCR detection of Leishmania infantum within human peripheral blood mononuclear cells. Acta Trop. 59: 187-196. http://dx.doi. org/10.1016/0001-706X(95)00079-T

Reis HR, Lopes-Mori FMR, Reis CR, Freire RL, et al. (2011). Soroprevalência da leishmaniose tegumentar americana (LTA) canina e fauna de flebotomíneos (Diptera: Psychodidae) em Bela Vista do Paraíso, Paraná. Semin. Cienc. Agrar. 32: 1083-1094. http://dx.doi.org/10.5433/1679-0359.2011v32n3p1083

Reithinger R and Davies CR (1999). Is the domestic dog (Canis familiaris) a reservoir host of American cutaneous leishmaniasis? A critical review of the current evidence. Am. J. Trop. Med. Hyg. 61: 530-541.

Reithinger R, Lambson BE, Barker DC and Davies CR (2000). Use of PCR to detect Leishmania (Viannia) spp. in dog blood and bone marrow. J. Clin. Microbiol. 38: 748-751.

Rodrigues EHG (2000). Validation of molecular approaches for the diagnosis of American cutaneous leishmaniasis in Pernambuco State. Rev. Inst. Med. Trop. Sao Paulo 42: 326.

Rondon FC, Bevilaqua CM, Franke CR, Barros RS, et al. (2008). Cross-sectional serological study of canine Leishmania infection in Fortaleza, Ceará state, Brazil. Vet. Parasitol. 155: 24-31.http://dx.doi.org/10.1016/j.vetpar.2008.04.014

Santos JM, Dantas-Torres F, Mattos MR, Lino FR, et al. (2010). [Prevalence of anti-Leishmania spp antibodies in dogs from Garanhuns, in the middle scrub zone (Agreste) of Pernambuco]. Rev. Soc. Bras. Med. Trop. 43: 41-45. http:// dx.doi.org/10.1590/S0037-86822010000100010

Schubach A, Cuzzi-Maya T, Oliveira AV, Sartori A, et al. (2001). Leishmanial antigens in the diagnosis of active lesions and ancient scars of American tegumentary leishmaniasis patients. Mem. Inst. Oswaldo Cruz 96: 987-996. http:// dx.doi.org/10.1590/S0074-02762001000700018

Serra CM, Leal CA, Figueiredo F, Schubach TM, et al. (2003). [Canine tegumentary leishmaniasis in Morada das Aguias (Serra da Tiririca), Maricá, Rio de Janeiro, Brazil]. Cad. Saude Publica 19: 1877-1880. http://dx.doi.org/10.1590/ $\underline{\text { S0102-311X2003000600032 }}$

Silveira TG, Teodoro U, Lonardoni MV, Guilherme AL, et al. (1996). [Epidemiologic aspects of Cutaneous Leishmaniasis in an endemic area of the state of Paraná, Brazil]. Cad. Saude Publica 12: 141-147. http://dx.doi.org/10.1590/S0102$\underline{311 X 1996000200003}$

Solano-Gallego L, Llull J, Ramis A, Fernández-Bellon H, et al. (2005). Longitudinal study of dogs living in an area of Spain highly endemic for leishmaniasis by serologic analysis and the leishmanin skin test. Am. J. Trop. Med. Hyg. 72: 815-818.

Velasquez LG, Membrive N, Membrive U, Rodrigues G, et al. (2006). PCR in the investigation of canine American tegumentary leishmaniasis in northwestern Paraná State, Brazil. Cad. Saude Publica 22: 571-578. http://dx.doi. org $/ 10.1590 / \mathrm{S} 0102-311 X 2006000300012$

Werneck GL, Costa CH, Walker AM, David JR, et al. (2007). Multilevel modelling of the incidence of visceral leishmaniasis in Teresina, Brazil. Epidemiol. Infect. 135: 195-201.http://dx.doi.org/10.1017/S0950268806006881

World Health Organization (2015). Leishmaniasis. Available at [http://www.who.int/leishmaniasis/burden/en/]. Accessed November 13, 2015.

Zanzarini PD, dos Santos DR, dos Santos AR, de Oliveira O, et al. (2005). [Canine American cutaneous leishmaniasis in municipalities of northern Paraná State, Brazil]. Cad. Saude Publica 21: 1957-1961. http://dx.doi.org/10.1590/ $\underline{\text { S0102-311X2005000600047 }}$

Genetics and Molecular Research 15 (3): gmr.15038684 